BIORHEOLOGY, $21 ; 1-4,1984$

0006-355X $\$ 3.00+.00$ Printed in the USA.

Copyright (c) 1984 Pergamon Press Ltd. A11 rights reserved.

\title{
PREFACE AND EDITORIAL
}

This double issue of BIORHEOLOGY, comprising issues 1 and 2 of volume 21 , is dedicated to Hellmut Hartert, the seventh recipient of the Poiseuille Gold Medal Award. His portrait is placed as a frontispiece in this special issue. The Poiseuille Award is the highest honor by the International Society of Biorheology which was bestowed upon Hellmut Hartert at the Fifth International Congress of Biorheology, held at the Congress House in Baden-Baden, West Germany from 20-24 August 1983. The Proceedings of the Convocation and Poiseuille Award Ceremony are contained in this issue.

Hellmut Hartert was the Honorary President of the Fifth International Congress of Biorheology. Its President was Siegfried Witte, President of the International Society of Biorheology. Konrad Messmer was the Secretary General of the Congress.

A report on the Congress by President Witte is presented in this issue. Upon the invitation of the Congress Chairman and the Organizing Committee of the Congress, Mr. L. Alcopley was asked to design a drawing which would symbolize the science of biorheology. This drawing appeared on the cover of the Congress program and is reproduced in this issue.

The fourth day of our Congress was held together with the first day of the 3. European Conference on Clinical Haemorheology, which took place from 24-27 August 1983. At this joint meeting, John A. Dormandy received the Fahraeus Award of the 3. European Conference on Clinical Haemorheology. His Fahraeus Award Lecture will appear in CLINICAL HEMORHEOLOGY. It should be noted that the Fånraeus Medal is not an award of the International Society of Biorheology. Its only award is the Poiseuille Gold Medal.

We should like to clarify another matter. We regret that, instead of the International Society of Biorheology, the name In- 
ternational Society on Biorheology was inadvertently used. At all Congresses of the International Society of Biorheology, the name was always "International Congress of Biorheology". We trust that this usage will be kept for future congresses of the International Society of Biorheology.

A.1 texts presented at the Fahraeus Award Ceremony will appear as part of the Proceedings of the 3. European Conference on Clinical Haemorheology in CIINICAL HEMORHEOLOGY, our Society's second official journal. It is the companion journal of BIORHEOLOGY, the Society's main official journal.

This special issue contains the six Plenary Lectures and two Symposia. They are: (I) "Permeability and the Blood Vessel Wall", edited by its Chairpersons, Co-Editor-in-Chief Alex Silberberg and Guest Editor Harold Wayland. (II) "Normal and Pathological Mucus", edited by its Chairperson Guest Editor Edith Puchelle. Six of the remaining nine Congress Symposia will appear as part of the Congress Proceedings in subsequent issues of BIORHEOLOGY, while three Congress Symposia dealing with clinical hemorheology will be published in CLINICAL HEMORHEOLOGY. It should likewise be noted that Congress Papers, which were submitted to any of our Editors and accepted for publication by them, appear in this and subsequent issues of BIORHEOLOGY. These issues will contain under separate headings both Congress Papers and Non-Congress Papers.

There was one Satellite Meeting of the Fifth International Congress of Biorheology under the presidency of J.F. Stoltz, held at Nancy, France from 17-18 August 1983 and entitled "New Methods in Biorheology". Its Honorary Committee was composed of A.L. Copley, A. Silberberg and S. Witte. A.L. Copley acted as Honorary President and presented the introductory lecture. The Proceedings of the Satellite Meeting, edited by J.F. Stoltz, will appear as Supplement I of BIORHEOLOGY. It will be made available free of charge to all subscribers of BIORHEOLOGY and is expected to be published soon.

The President of the International Society of Biorheology, elected at the Business Meeting of the Society in Baden-Baden, is Harry L. Goldsmith. The Society's Secretary and Treasurer are Herbert J. Meiselman and Joseph F. Gross, respectively. The next 
Congress of the Society is scheduled to take place in Vancouver, Canada and the elected Congress President is Donald E. Brooks.

Finally, it gives us great pleasure to congratulate our colleague and friend Hellmut Hartert, to the great honor of his Poiseuille Award. We feel certain that our congratulations are shared by our Readers.

Our best wishes, shared by Alex Silberberg, go to the Readers of BIORHEOLOGY for a happy and scientifically profitable New Year!

Alfred L. Copley and Siegfried Witte 


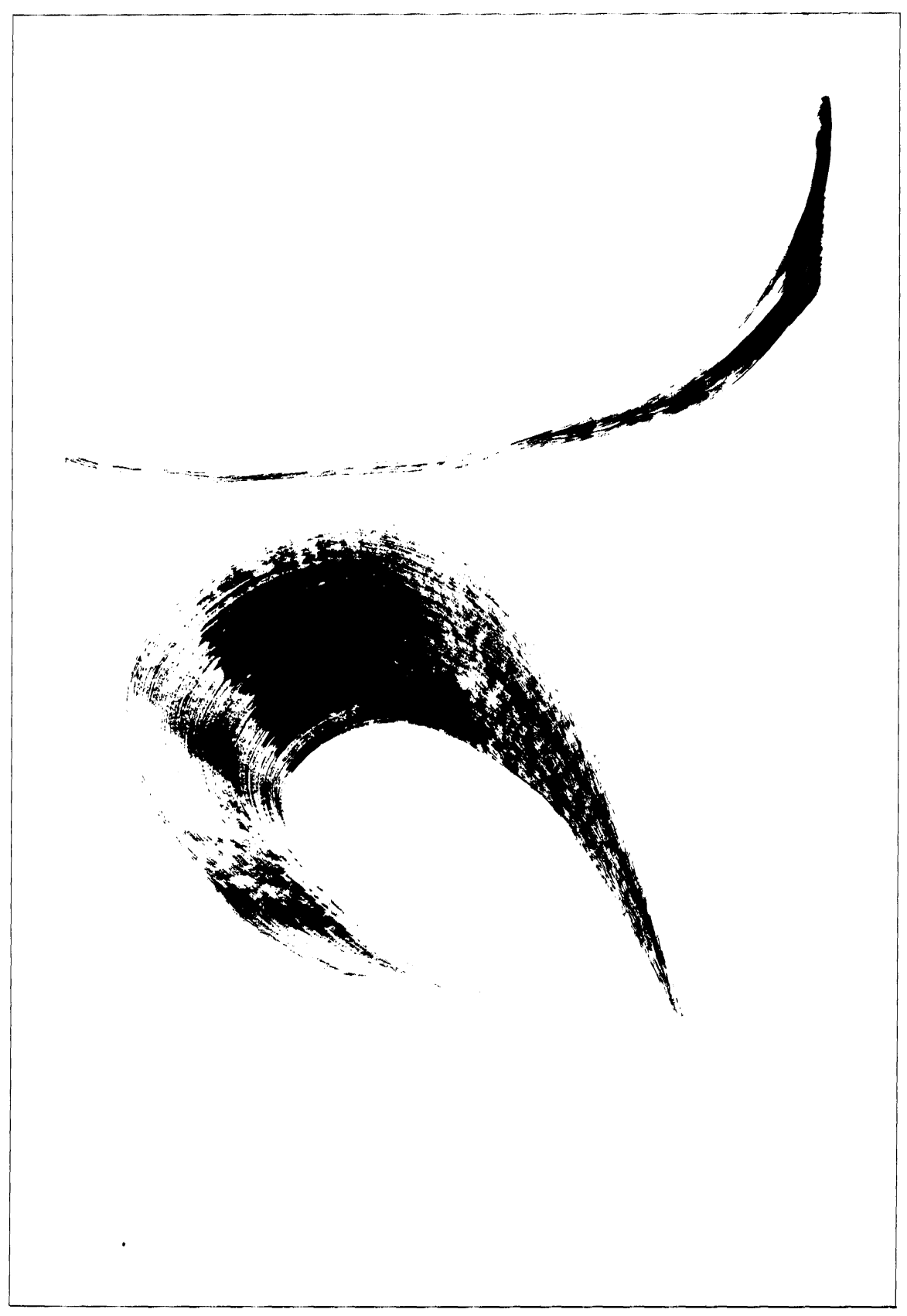

On front cover of Congress Program, reproduction of picture (49x $34 \mathrm{~cm}$, in acrylic) painted in 1983 by L. Alcopley upon request of Congress Chairman Siegfried Witte. It is titled "Theme of Biorheology II". (See: Biorheology, 15, 400, 1978, where "Theme of Biorheology I" was reproduced). 